\title{
Etiological evaluation in 766 patients with pancytopenia; a single center experience
}

\section{Pansitopenisi olan 766 hastada etyolojik değerlendirme; tek merkez deneyimi}

\author{
Betül Erismis $^{{ }^{*}(\mathbb{D})}$, Gamze Gulcicek ${ }^{1}$ (D), Medine Sisman ${ }^{2}$ (D), Betul Yildirim Ozturk ${ }^{1}$ (D), Deniz Yilmaz ${ }^{1}$ (D), \\ Itir Sirinoglu Demiriz ${ }^{3}$ (i) \\ 1 Bakirkoy Dr. Sadi Konuk Training and Research Hospital, Internal Medicine Department, Istanbul, Turkey \\ ${ }^{2}$ Bakirkoy Dr. Sadi Konuk Training and Research Hospital, Family Medicine Department, Istanbul, Turkey \\ ${ }^{3}$ Bakirkoy Dr. Sadi Konuk Training and Research Hospital, Hematology Department, Istanbul, Turkey \\ * Corresponding author: Betül Erismis E-mail: betul_erismis@yahoo.com ORCID: 0000-0003-2970-2076 \\ Received: 31 May 2019 Accepted: 5 March 2020
}

\begin{abstract}
Aim: Pancytopenia is a clinical problem which has a wide differential diagnostic spectrum and may occur with various mechanisms. In this study we aimed to determine the most common etiologic causes in patients with pancytopenia.

Materials and Methods: The records of patients aged 18 years and older, who applied to the Health Sciences University Bakirkoy Dr. Sadi Konuk Training and Research Hospital between 2012 and 2017 and who were diagnosed with pancytopenia according to World Health Organization (WHO) criteria were retrospectively reviewed. Statistical Method: Mann-Whitney-U test was used for 2 groups and Kruskal-Wallis test was applied for 3 and more groups. Since no normal distribution was provided as a descriptive statistic, median and change interval values were given for continuous data.
\end{abstract}

Results: A total of 766 patients, 475 (62\%) women and 291(38\%) men, were included in the study. In these patients, nonhematologic causes were found in $77.7 \%$ and hematologic causes in $22.3 \%$ of patients with pancytopenia. Hematological etiologies were $72.2 \%$ benign and $27.8 \%$ malignant. Non-hematological causes were divided into groups as renal diseases $(6.05 \%)$, rheumatological diseases (2.3\%), infective diseases (10.7\%), endocrinological diseases (3.8\%), hypersplenism (14.4\%), immunosuppressive drug use (17.4\%), solid organ cancers (10.7\%) and unidentified reasons (34.2\%).

Conclusion: Pancytopenia should be evaluated carefully and the etiology should be detected quickly and corrected by appropriate treatment. It is an appropriate approach to exclude, firs the non-hematological causes (especially immunosuppressive drug use, hypersplenism, infection and solid organ cancers) and the benign causes of hematological reasons.

Keywords: pancytopenia, anemia, leukopenia, thrombocytopenia, malignancy

() 2020 by the authors; licensee MEDITAGEM Ltd., Turkey. This article is an open access article distributed under the terms and conditions of the Creative Commons Attribution License (http://creativecommons.org/licenses/by/4.0/). 


\section{ÖZ}

Amaç: Pansitopeni, çeşitli mekanizmalarla ortaya çıkabilen ve geniş bir ayırıcı tanı spektrumuna sahip klinik bir problemdir. Bu çalışmada pansitopenili hastalarda en sık görülen etiyolojik nedenleri belirlemeyi amaçladık.

Gereç ve Yöntem: Sağlık Bilimleri Üniversitesi Bakırköy Dr. Sadi Konuk Eğitim ve Araştırma Hastanesi’ne $2012-2017$ yılları arasında başvuran ve Dünya Sağlık Örgütü kriterlerine göre pansitopeni tanısı alan 18 yaş ve üstü hastaların kayıtları retrospektif olarak incelendi.

İstatistiksel Yöntem: İkili gruplara Mann-Whitney-U testi, 3 ve daha fazla grubun olduğu karşılaştırmalarda ise Kruskal-Wallis testi uygulandı. Tanımlayıcı bir istatistik olarak normal dağılım sağlanmadığından, sürekli veriler için ortanca ve değişim aralığı değerleri verildi. Bulgular: Çalışmaya 475 (\%62) kadın ve 291 (\%38) erkek olmak üzere toplam 766 hasta dahil edildi. Bu hastaların \%77,7'sinde hematolojik olmayan nedenler, \%22,3'ünde ise hematolojik nedenlerin pansitopeni etiyolojisinde rol oynadığı görüldü. Hematolojik etiyolojilerin \%72,2'si benign, \%27,8'i ise malign hastalıklardan oluşmaktaydı. Hematolojik olmayan nedenlerin ise; renal $(\% 6,05)$, romatolojik hastalıklar $(\% 2,3)$, enfektif hastalıklar $(\% 10,7)$, endokrinolojik hastalıklar $(\% 3,8)$, hipersplenizm $(\% 14,4)$, immünsupresif ilaç kullanımı $(\% 17,4)$, solid organ kanserleri $(\% 10,7)$ ve tanımlanamayan nedenler (\%34,2)'den oluştuğu görüldü.

Sonuç: Pansitopeni dikkatlice değerlendirilerek etiyolojisi hızlı bir şekilde tespit edilmeli ve uygun tedavi ile düzeltilmelidir. Öncelikle hematolojik olmayan nedenlerin (özellikle immünsupresif ilaç kullanımı, hipersplenizm, enfeksiyon ve solid organ kanserleri) ve hematolojik nedenlerden de benign hastalıkların dışlanması uygun bir yaklaşımdır.

Anahtar kelimeler: pansitopeni, anemi, lökopeni, trombositopeni, malignite

\section{INTRODUCTION}

The definition of pancytopenia adopted by WHO includes the combination of all here parameters: Hemoglobin $(\mathrm{Hb})$ for non-pregnant women $<12 \mathrm{~g} / \mathrm{dl}$ and $<13 \mathrm{~g} / \mathrm{dl}$ for men, absolute neutrophile count $<1800$ /microl, platelet count $<150000 / \mathrm{mm} 3$ [1]. In healthy adults, hematopoiesis occurs in the bone marrow where mature blood cells migrate to other regions with the circulatory system. The balance between blood cell production, distribution in other organs, and ongoing cellular destruction determines the levels of circulating blood cells [2-5]. Pancytopenia may occur with various mechanisms. The etiologic classification consists of bone marrow infiltration (hematological malignancies, metastatic cancers, myelofibrosis and infectious diseases, tuberculosis, fungal infections, etc.), bone marrow aplasia (vitamin B12 or folate deficiency, aplastic anemia, infectious diseases such as HIV infection, viral hepatitis, parvovirus B19 infection and drugs) and blood cell destruction or sequestration (disseminated intravascular coagulation, thrombotic thrombocytopenic purpura, ineffective erythropoiesis, myelodysplastic syndrome, megaloblastic disorders, hypersplenism). Although pancytopenia is a common clinical problem with a wide differential spectrum, there is not enough information about the incidence of causes except for a few studies [6-8]. In our study, the aim was to determine the most common etiologies in patients with pancytopenia and to contribute to the shortening of the transition period for appropriate treatment by making a rapid diagnosis.

\section{MATERIALS AND METHODS}

The records of patients, who were applied to our internal medicine outpatient clinics between 2012 - 2017 and diagnosed with pancytopenia according to WHO criteria were retrospectively analyzed. Gender, age, $\mathrm{Hb}$, hematocrit (Hct), white blood cell count (WBC), platelet count, mean corpuscular volume (MCV), lactate dehydrogenase (LDH), vitamin B12, folate, serum iron, ferritin, thyroid stimulating hormone (TSH), free thyroxine (fT4), drug (immunosuppressive) use, presence of hepatomegaly and/or splenomegaly were recorded. The patients were divided into 2 groups according to hematological and nonhematological etiologies, which primarily led to pancytopenia. Hematologic etiology group was further divided into two groups as benign and malignant causes. The non-hematologic etiological group was further divided into subgroups as; infectious diseases, rheumatologic diseases, endocrinological diseases, renal diseases, hypersplenism, immune suppressive drug use, solid organ cancers and others (undetectable).

\section{STATISTICAL METHOD}

Normality tests were performed for each variable and Kolmogorov-Smirnov and Shapiro-Wilk tests were 


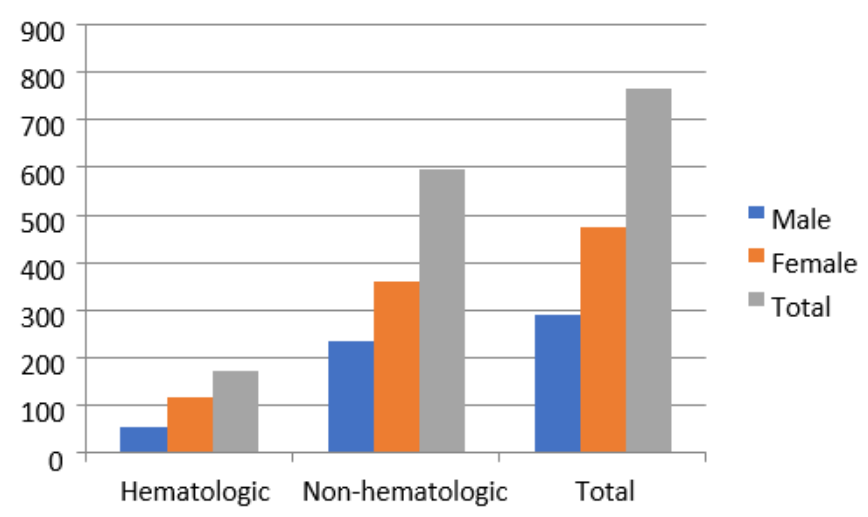

Figure 1. Gender distribution among groups

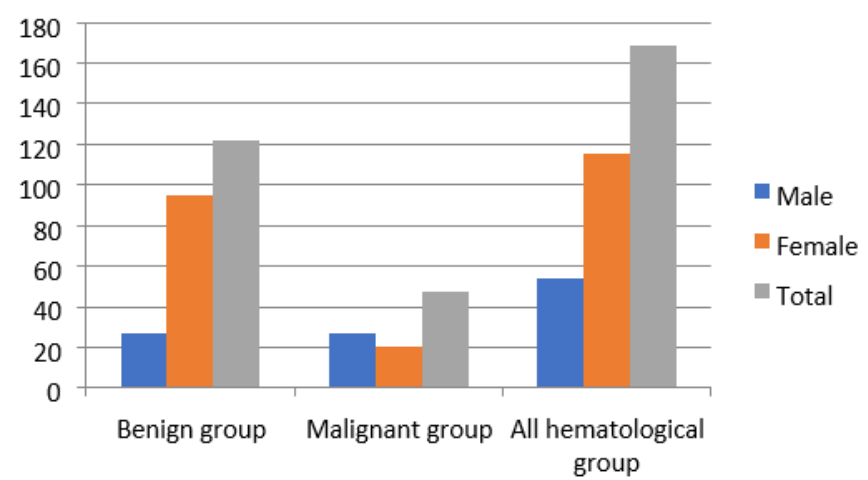

Figure 2. Gender distribution between hematological subgroups

performed. Since the variables were not normally distributed due to $p<0.05$, non-parametric methods were preferred in the analyzes. Mann-Whitney-U test was used for 2 groups and Kruskal-Wallis test was used for 3 and more groups. Since no normal distribution was provided as a descriptive statistic, median and change interval (max-min) values were given for continuous data. Frequency distribution tables for categorical data were interpreted. Data are presented as percentage and number. The analyzes were performed with SPSS 22.0 statistical analysis program and significance level was considered as $p<0.05$.

\section{RESULTS}

A total of 766 patients, 475 (62\%) women and 291 (38\%) men, were included. The mean age of men was 60.6 years, the mean age of women was 55.5 years, and the average age of all patients was 57.5 years. Non-hematological causes were found in $77.7 \%$ and hematological causes in $22.3 \%$ of patients with pancytopenia. Gender distribution among both groups is shown in Figure 1. Hematological etiologies were $72.2 \%$ benign and $27.8 \%$ malignant. Gender distribution in hematological subgroups is shown in Figure 2. Non-hematological causes were divided into groups as renal diseases (6.05\%), rheumatological diseases (2.3\%), infective diseases (10.7\%), endocrinological diseases (3.8\%), hypersplenism (14.4\%), immunosuppressive drug use $(17.4 \%)$, solid organ cancers $(10.7 \%)$ and unidentified
Table 1. Non-hematological group gender-etiology distribution

\begin{tabular}{|l|c|c|c|}
\hline Etiology & Male & Female & Total / \% \\
\hline Infectious causes & 22 & 42 & $64 / 10.7$ \\
\hline Rheumatological causes & 0 & 14 & $14 / 2.3$ \\
\hline Hypersplenism & 33 & 53 & $86 / 14.4$ \\
\hline Endocrinological causes & 5 & 18 & $23 / 3.8$ \\
\hline Immunosuppressive drug use & 49 & 55 & $104 / 17.4$ \\
\hline Renal causes & 18 & 18 & $36 / 6.05$ \\
\hline Solid organ cancers & 38 & 26 & $64 / 10.7$ \\
\hline Other reasons & 71 & 133 & $204 / 34.2$ \\
\hline Total & $\mathbf{2 3 6}$ & $\mathbf{3 5 9}$ & $\mathbf{5 9 5} / \mathbf{1 0 0}$ \\
\hline
\end{tabular}

Table 2. Differences between hematological and nonhematological groups of variables, Mann-Whitney-U statistics

\begin{tabular}{|c|c|c|c|c|c|}
\hline & Group & $\mathbf{N}$ & $\begin{array}{c}\text { Average } \\
\text { rank }\end{array}$ & $\begin{array}{c}\text { Mann- } \\
\text { Whitney-U } \\
\text { statistics }\end{array}$ & $\mathbf{p}$ \\
\hline \multirow{2}{*}{ Age } & Hematologic & 171 & 352.41 & \multirow{2}{*}{45556} & \multirow{2}{*}{0.024} \\
\hline & Non-hematologic & 595 & 392.44 & & \\
\hline \multirow{2}{*}{$\mathrm{Hb}$} & Hematologic & 171 & 373.93 & \multirow{2}{*}{49236} & \multirow{2}{*}{0.521} \\
\hline & Non-hematologic & 595 & 386.25 & & \\
\hline \multirow{2}{*}{$\mathrm{Hct}$} & Hematologic & 171 & 389.82 & \multirow{2}{*}{49791} & \multirow{2}{*}{0.671} \\
\hline & Non-hematologic & 595 & 381.68 & & \\
\hline \multirow{2}{*}{ WBC Count } & Hematologic & 171 & 372.79 & \multirow{2}{*}{49040} & \multirow{2}{*}{0.472} \\
\hline & Non-hematologic & 595 & 386.58 & & \\
\hline \multirow{2}{*}{$\begin{array}{l}\text { Platelet } \\
\text { Count }\end{array}$} & Hematologic & 171 & 384.25 & \multirow{2}{*}{50745} & \multirow{2}{*}{0.960} \\
\hline & Non-hematologic & 595 & 383.29 & & \\
\hline \multirow{2}{*}{ LDH } & Hematologic & 171 & 302.59 & \multirow{2}{*}{37036} & \multirow{2}{*}{$0.000 *$} \\
\hline & Non-hematologic & 595 & 406.75 & & \\
\hline \multirow[t]{2}{*}{ MCV } & Hematologic & 171 & 369.50 & \multirow{2}{*}{48478} & \multirow{2}{*}{0.346} \\
\hline & Non-hematologic & 595 & 387.52 & & \\
\hline \multirow{2}{*}{ TSH } & Hematologic & 171 & 144.42 & \multirow{2}{*}{8183.5} & \multirow{2}{*}{0.319} \\
\hline & Non-hematologic & 595 & 155.95 & & \\
\hline \multirow{2}{*}{ fT4 } & Hematologic & 171 & 124.73 & \multirow{2}{*}{5179.5} & \multirow{2}{*}{0.975} \\
\hline & Non-hematologic & 595 & 125.07 & & \\
\hline \multirow{2}{*}{ Serum iron } & Hematologic & 171 & 155.59 & \multirow{2}{*}{10917.5} & \multirow{2}{*}{$0.032 *$} \\
\hline & Non-hematologic & 595 & 176.03 & & \\
\hline \multirow{2}{*}{ Ferritin } & Hematologic & 171 & 137.38 & \multirow{2}{*}{9006.4} & \multirow[t]{2}{*}{$0.000^{*}$} \\
\hline & Non-hematologic & 595 & 181.61 & & \\
\hline 5 & Hematologic & 171 & 119.68 & 506 & \\
\hline & Non-hematologic & 595 & 117.97 & כ & 0.033 \\
\hline Vitamin & Hematologic & 171 & 140.60 & & \\
\hline B12 & Non-hematologic & 595 & 194.14 & $944 \% .1$ & 0.000 \\
\hline
\end{tabular}

Abbreviations: Hemoglobine, $\mathrm{Hb}$; hematocrit, Hct; white blood cell, WBC; lactate dehydrogenase, $\mathrm{LDH}$; mean corpuscular volume, $\mathrm{MCV}$; thyroid stimulating hormone, TSH; free thyroxine, fT4.

reasons (34.2\%). Gender and etiology distribution of nonhematological group is shown in Table 1. Differences between the hematological and non-hematological groups (Table 2) and benign and malignant groups from the hematological subgroups (Table 3) were shown in the tables below. Age $(p=0.024), \operatorname{LDH}(p=0.000)$, serum iron $(p=0.032)$, ferritin ( $p=0.000)$ and vitamin $B 12(p=0.000)$ levels were significantly higher in the non-hematological group. According to the comparison between hematological groups; $\mathrm{Hb}(p=0.000)$, Hct $(p=0.000), W B C(p=0.000)$ and 
Table 3. Differences between benign and malign hematological groups, Mann-Whitney-U test results

\begin{tabular}{|c|c|c|c|c|c|}
\hline & Group & $\mathbf{N}$ & $\begin{array}{c}\text { Average } \\
\text { rank }\end{array}$ & $\begin{array}{c}\text { Mann- } \\
\text { Whitney-U } \\
\text { statistics }\end{array}$ & $\mathbf{p}$ \\
\hline \multirow{2}{*}{ Age } & Benign & 122 & 79.88 & \multirow{2}{*}{2242.5} & \multirow{2}{*}{$0.023^{*}$} \\
\hline & Malignant & 47 & 98.29 & & \\
\hline \multirow{2}{*}{$\mathrm{Hb}$} & Benign & 122 & 93.73 & \multirow{2}{*}{1802.0} & \multirow{2}{*}{$0.000^{*}$} \\
\hline & Malignant & 47 & 62.34 & & \\
\hline \multirow{2}{*}{$\mathrm{Hct}$} & Benign & 122 & 93.43 & \multirow{2}{*}{1839.0} & \multirow{2}{*}{$0.000 *$} \\
\hline & Malignant & 47 & 63.13 & & \\
\hline \multirow{2}{*}{ WBC Count } & Benign & 122 & 93.23 & \multirow{2}{*}{1862.5} & \multirow{2}{*}{$0.000 *$} \\
\hline & Malignant & 47 & 63.63 & & \\
\hline \multirow{2}{*}{$\begin{array}{l}\text { Platelet } \\
\text { Count }\end{array}$} & Benign & 122 & 92.30 & \multirow{2}{*}{1977.0} & \multirow{2}{*}{$0.002^{*}$} \\
\hline & Malignant & 47 & 66.06 & & \\
\hline \multirow{2}{*}{ LDH } & Benign & 122 & 81.65 & \multirow{2}{*}{2458.5} & \multirow{2}{*}{0.151} \\
\hline & Malignant & 47 & 93.69 & & \\
\hline \multirow{2}{*}{ MCV } & Benign & 122 & 81.36 & \multirow{2}{*}{2422.5} & \multirow{2}{*}{0.113} \\
\hline & Malignant & 47 & 94.46 & & \\
\hline \multirow{2}{*}{ TSH } & Benign & 122 & 39.47 & \multirow{2}{*}{1567.8} & \multirow{2}{*}{0.584} \\
\hline & Malignant & 47 & 36.52 & & \\
\hline \multirow{2}{*}{ fT4 } & Benign & 122 & 24.29 & \multirow{2}{*}{1254.9} & \multirow{2}{*}{0.304} \\
\hline & Malignant & 47 & 28.65 & & \\
\hline \multirow{2}{*}{ Serum Iron } & Benign & 122 & 46.73 & \multirow{2}{*}{1796.3} & \multirow{2}{*}{$0.001 *$} \\
\hline & Malignant & 47 & 68.47 & & \\
\hline \multirow{2}{*}{ Ferritin } & Benign & 122 & 46.70 & \multirow{2}{*}{1952.2} & \multirow{2}{*}{$0.000 *$} \\
\hline & Malignant & 47 & 72.23 & & \\
\hline Folate & Benign & 122 & 34.58 & 1162.1 & 0.378 \\
\hline rolde & Malignant & 47 & 39.38 & 1102.1 & $0.3 \%$ \\
\hline Vitamin B12 & Benign & 122 & 50.52 & 1836.3 & $0.004 *$ \\
\hline & Malignant & 47 & 70.15 & & \\
\hline
\end{tabular}

${ }^{*} \mathrm{p}<0.05$

Abbreviations: Hemoglobine, $\mathrm{Hb}$; hematocrit, $\mathrm{Hct}$; white blood cell, WBC; lactate dehydrogenase, $\mathrm{LDH}$; mean corpuscular volume, MCV; thyroid stimulating hormone, $\mathrm{TSH}$; free thyroxine, $\mathrm{fT} 4$.

Table 4. Evaluation of abdominal ultrasonography results

\begin{tabular}{|c|c|}
\hline Abdominal Ultrasonography Report & Patients (n) \\
\hline Hepatomegaly & $55(17.2 \%)$ \\
\hline Splenomegaly & $92(28 \%)$ \\
\hline Total & $319(100 \%)$ \\
\hline
\end{tabular}

platelet count $(p=0.002)$ were significantly higher in benign hematological group. Serum iron $(p=0.001)$, ferritin $(p=0.000)$ and vitamin B12 $(p=0.004)$ levels were significantly higher in the malignant hematological group. $55(17.2 \%)$ out of 319 patients with abdominal ultrasonography had hepatomegaly and 92 (28.8\%) had splenomegaly (Table 4).

\section{DISCUSSION}

Pancytopenia can be fatal if it cannot be diagnosed early [9]. Therefore, rapid detection of the underlying cause is extremely important in terms of coping with the disease and prognosis. It is important to investigate the most common pancytopenia etiologies and ones which may be less frequent but more serious, in the differential diagnosis.
In our study, we investigated whether we can predict the etiologies with hemogram and routine biochemistry results. As expected, in table 2, we observed significant differences between LDH, ferritin, serum iron and vitamin B12 among the hematological and non-hematological groups. In table 3, we obtained significantly lower $\mathrm{Hb}, \mathrm{Hct}, \mathrm{WBC}$, platelet counts and higher serum iron, ferritin and vitamin B12 levels between malignant and bening hematological subgroups. These findings were indicative for our correct grouping.

In our study we found that the mean age of all patients was 57.5 and there was a female dominance with the percentage of 62. Gayathri BN et al. reported a mean age of 41 years and male gender as a dominant in a prospective study of 104 pancytopenia patients aged between 2 and 80 years in India. The difference in mean age was considered to be related only to the inclusion of the adult population in our study. Also, splenomegaly was more common than hepatomegaly in their study [10]. In our study abdominal ultrasound was performed less than half of the patients (319 patients) but consistently with this study splenomegaly was more common than hepatomegaly with the percentage of 28.8 . M. Premkumar et al. found that the mean age was 32.8 and male gender was dominant in their study which evaluating the hematological etiology with 140 pancytopenia patients. As the etiological frequency; megaloblastic anemia (60.7\%), infectious causes (16.4\%), aplastic anemia (7.8\%) and leukemia (9.2\%) were detected [11]. Inconsistently with this study we found that the most common etiologic causes were non-hematological causes with the percentage of $77.7 \%$. But similar to literature, we showed that benign causes $(72.8 \%)$ were more frequently in the hematological etiology. In a study conducted by Imbert et al., with 213 adult pancytopenia patients in France, it was observed that malign hematological causes were more frequent and that was again not compatible with our study. According to this study, malignant myeloid disorders (acute myeloid leukemia, MDS and myelofibrosis) $42 \%$ and malignant lymphoid disorders $18 \%$ accounted for $60 \%$ of all hematological etiologies. The group containing the benign etiologies such as megaloblastic anemia was found to be $17 \%$ (8). It was thought that this difference could be related with adequate nutrition and socio-cultural level of the patient population. Hayat AS and at al. found that $72.94 \%$ of the patients were male and $27.05 \%$ were female in their study. In the etiological evaluation, they found that noncancerous causes were more frequent with a rate of $63.52 \%$ [12]. Yadav BS and at al. found the mean age of 35.15 \pm 12.6 years and an equal female/male ratio in gender distribution, in their study with 58 pancytopenia patients 
above the age of 18 [13]. In the study of Dubey TN and et al., which included 70 patients over 13 years of age, the male/female ratio was $1.4 / 1$. In the etiological evaluation, megaloblastic anemia was in the first place with a rate of $41.4 \%$. Aplastic anemia with the ratio of $22.9 \%$, hypersplenism $15.7 \%$ and leukemic diseases $14.2 \%$ were also found in the etiology [14].

The shortcomings of our study were; it was retrospective and imaging and pathological examinations were not applied to all patients. We believe that the prospective studies with many more patients will shorten the algorithms applied to diagnose patients who apply with pancytopenia.

\section{CONCLUSION}

Pancytopenia should be evaluated carefully and the etiology should be detected quickly and corrected by appropriate treatment. In studies conducted, gender dominance is different for each study, so it is not true to say that pancytopenia is more common in male or female sex. According to our study, it is an appropriate approach to exclude, first the non hematological causes (especially immunosuppressive drug use, hypersplenism, infection and solid organ cancers, respectively) and the benign causes of hematological reasons. When family physicians encounter patient with pancytopenia, they should be calm and after diagnosis treat the benign causes. If there is no benign cause then they should refer the patients to advanced center immediately.

\section{DECLARATION OF CONFLICT OF INTEREST}

The authors received no financial support for the research and/or authorship of this article. There is no conflict of interest.

\section{REFERENCES}

1. Valent P. Low blood counts: immune mediated, idiopathic, or myelodysplasia. Hematology Am Soc Hematol Educ Program 2012; 2012: 485-91.

2. Young NS, Abkowitz JL, Luzzatto L. New insights into the pathophysiology of acquired cytopenias. Hematology Am Soc Hematol Educ Program 2000: 18-38.

3. Pascutti MF, Erkelens MN, Nolte MA. Impact of viral infections on hematopoiesis: from beneficial to detrimental effects on bone marrow output. Front Immunol 2016; 7(364): 1-12.
4. Marks PW. Hematologic manifestations of liver disease. Seminars in hematology 2013; 50: 216-21.

5. Risitano AM, Maciejewski JP, Selleri C, Rotoli B. Function and malfunction of hematopoietic stem cells in primary bone marrow failure syndromes. Curr Stem Cell Res Ther. 2007; 2(1): 39-52.

6. Savage DG, Allen RH, Gangaidzo IT, Levy LM, Gwanzura C, Moyo A, et al. Pancytopenia in Zimbabwe. Am J Med Sci 1999; 317(1): 22-32.

7. Tilak V, Jain R. Pancytopenia - A Clinico hematologic analysis of 77 cases. Indian J Pathol Microbiol 1999; 42(4): 399-404.

8. Imbert M, Scoazec JY, Mary JY, Jouzult H, Rochant $H$, Sultan C. Adult patients presenting with pancytopenia: a reappraisal of underlying pathology and diagnostic procedures in 213 cases. Hematol Pathol 1989; 3(4): 15967.

9. Khodke K, Marwah S, Buxi G, Yadav RB, Chaturvedi NK. Bone marrow examination in cases of pancytopenia. J Indian Acad Clin. Med 2001; 2: 55-9.

10. Gayathri BN, Rao KS. Pancytopenia: a clinico hematological study. J Lab Physicians 2011; 3(1): 15-20.

11. Premkumar M, Gupta N, Singh T, Velpandian T. Cobalamin and folic Acid status in relation to the etiopathogenesis of pancytopenia in adults at a tertiary care centre in north India. Anemia 2012; 2012: 707402.

12. Hayat AS, Khan AH, Baloch GH, Shaikh N. Pancytopenia; study for clinical features and etiological pattern of at tertiary care settings in Abbottabad. Professional Med J 2014; 21(1): 060-065.

13. Yadav BS, Varma A, Kiyawat P. Clinical profile of pancytopenia: a tertiary care experience. Int. J. Bioassays 2015; 4(01): 3673-3677.

14. Dubey TN, Nigotia P, Saxena R. The Common Causes Leading to Pancytopenia in Patients Presenting in Hospital of Central India. International Journal of Contemporary Medical Research 2016; 3(10): 3027-3030. 